\title{
POTENSI ISOLAT Bacillus sp. ENG-4 YANG BERASOSIASI DENGAN SPONS Aplysina sp. PENGHASIL SENYAWA ANTIMIKROB ASAL PULAU ENGGANO
}

\author{
Risky Hadi Wibowo ${ }^{1}$, Sipriyadi ${ }^{1}$, Welly Darwis ${ }^{1}$ Santi Nurul \\ Kamilah ${ }^{1}$, Hizkia Puspa Pertiwi ${ }^{1}$, Reza Pertiwi ${ }^{2}$ \\ ${ }^{1}$ Program Studi Biologi, Fakultas Matematika dan IImu Pengetahuan Alam, \\ Universitas Bengkulu, Bengkulu, Indonesia \\ ${ }^{2}$ Program Studi Farmasi, Fakultas Matematika dan IImu Pengetahuan \\ Alam, Universitas Bengkulu, Bengkulu, Indonesia \\ E-mail: riskyhadiwibowo80@gmail.com
}

Received December 2019, Accepted February 2020

\begin{abstract}
ABSTRAK
Pulau Enggano merupakan salah satu pulau terluar di Indonesia yang memiliki keragaman biota yang cukup tinggi, salah satunya adalah hewan spons. Spons adalah sekelompok hewan multiseluler, memiliki ciri tubuh berpori, dan organisme invertebrata berguna dalam memproduksi senyawa bioaktif. Bakteri yang terkait dengan spons dapat menjadi sumber alternatif senyawa bioaktif baru, terutama antimikrob. Penelitian ini bertujuan untuk mengetahui potensi bakteri yang terkait dengan Aplysina sp. asal Pulau Enggano sebagai penghasil senyawa antimikrob melawan mikrob patogen. Total 263 isolat berhasil diisolasi pada media agar-agar Sea water Complete (SWC). Isolat bakteri potensial selanjutnya diidentifikasi dengan pengamatan morfologi, pewarnaan Gram, serta dilanjutkan dengan uji biokimia. Hasil uji aktivitas antimikrob dari 16 isolat terpilih melalui uji antagonis, supernatan dan pelet terhadap mikrob patogen Escherichia coli, Staphylococcus aureus, Pseudomonas aeroginosa dan Candida albicans menunjukkan bahwa isolat ENG-4 memiliki kemampuanmenghambat pada dua mikrob pathogen yaitu $E$. coli, S. aureus. Isolat ENG-4 termasuk ke dalam bakteri gram positif dan merujuk pada genus Bacillus berdasarkan uji biokimia.
\end{abstract}

Kata kunci: Antimikrob, Aplysina sp., Uji Antagonis, Senyawa Antimikrob, Pulau Enggano

\section{ABSTRACT}

POTENTIAL OF ISOLATE Bacillus sp. ENG-4 ASSOCIATED WITH MARINE SPONGE Aplysina sp. PRODUCING ANTIMICROBIAL COMPOUNDS FROM ENGGANO ISLAND. Enggano Island is one of the outer islands in Indonesia that has a high diversity of marine biota, one of them are sponges. Sponge is a group of multicellular animals, has a 
characteristic porous body, and invertebrate organisms are useful in producing bioactive compounds. Bacteria associated with sponges can be an alternative source of new bioactive compounds, especially antimicrobial. This study aims to determine the potential of bacteria associated with Aplysina sp. from Enggano island as a producer of antimicrobial compounds against pathogenic microbes. Total 263 isolates were successfully isolated in Sea water Complete (SWC) agar media. Potential isolates were further identified morphologically, Gram staining, and also biochemical tests. The results of the antimicrobial activity test of 16 selected isolates through antagonist, supernatant and pellet tests on pathogenic microbes of Escherichia coli, Staphylococcus aureus, Pseudomonas aeroginosa and Candida albicans showed that the ENG-4 isolate had the ability to inhibit two spesies of pathogens which are E. coli and $S$. aureus. ENG-4 isolate belong to gram-positive bacteria and refer to the genus Bacillus based on biochemical tests.

Keywords : Antimicrobial, Aplysina sp., Antagonist Test, Antimicrobial Compound, Enggano Island

\section{PENDAHULUAN}

Pulau Enggano merupakan salah satu pulau yang berada terdepan di Provinsi Bengkulu. Lokasi pantai di Pulau Enggano merupakan daerah yang langsung menghadap samudera Hindia dengan ombak yang besar sehingga mempengaruhi kehidupan biota laut di sekitarnya. Ekosistem yang ada di laut digunakan sebagai sumber dari berbagai senyawa organik dengan berbagai komposisinya sehingga dapat memelihara kehidupan dan ekosistem yang ada didalamnya (Ratnakomala et al., 2016). Berdasarkan penelitian yang dilakukan oleh (Senoaji et al., 2007), Pulau Enggano merupakan pulau yang mempunyai potensi besar untuk berkembang dan dapat menjadi kawasan pariwisata jika dilihat berdasarkan analisis kesesuaian lahannya. Tidak hanya sumber daya lingkungan, namun potensi pantai dan laut di Pulau Enggano ini masih belum banyak dieksplorasi, sehingga sumber daya yang tersediapun masih sangat alami. Salah satu keindahan laut yang dapat dinikmati di Pulau Enggano adalah Spons.

Spons merupakan kelompok biota laut yang bersimbiosis dengan komunitas mikrob, dimana spons berfungsi sebagai inang bagi kelompok tersebut (Webster dan Hill, 2001). Menurut Taylor, dkk., (2007), senyawa bioaktif dari spons dapat digunakan sebagai antibakteri, antifungi, antitumor dan antikanker. Hentschel et al. (2001) telah berhasil mengisolasi 27 isolat yang memiliki aktivitas antimikrob dari spons Aplysina aerophoba dan Aplysina cavercola yang mampu menghambatpertumbuhan $S$. aureus yaitu dari anggota genus Bacillus (SB8 dan SB17), Enterococcus (SB91), Arthrobacter (SB95), Unidentified low $\mathrm{G}+\mathrm{C}$ Gram positive (SB122 dan SB144), a proteobacteria (SB6, SB55, SB65,dan SB156,). Dengan demikian, potensi spons Aplysina sp yang berasal dari Pulau Dua, Kecamatan Enggano diharapkan dapat 
mengangkat dan memperkenalkan kearifan lokal yang ada di P. Enggano sehingga dapat menjadi prospek penting di bidang kesehatan.

\section{MATERI DAN METODE}

\section{Materi Penelitian}

Alat dan bahan yang digunakan pada penelitian ini adalah cawan Petri, tabung reaksi, mortar dan alu, erlenmeyer, gelas beker, gelas ukur, bunsen, jarum ose, pipet tetes, sentrifugasi, Laminar Air Flow (LAF), autoklaf, kertas cakram, hot plate, media urea, SWC (Sea Water Complete), PDB (Potato Dextrose Broth), PDA (Potato Dextrose Agar), NA (Nutrient Agar), SCA (Simon Citrat Agar), TSA (Tryptic Soy Agar), TSB (Tryptic Soy Broth) isolat mikrob patogen Escherichia coli, Staphylococcus aureus, Pseudomonas aeruginosa dan Candida albicans.

\section{Koleksi Spons Aplysina sp. dan Analisis Laboratorium}

Sampel diperoleh dari perairan laut Pulau Dua, Kecamatan Enggano menggunakan metode purposive sampling dimana 3 objek mewakili setiap 1 titik dengan interval masing - masing titik 10 meter ke arah horizontal dengan kedalaman 1-2 meter. Sampel yang didapat langsung dilakukan preparasi di lapangan. Selanjutnya dilakukan analisis di Laboratorium Mikrobiologi dan Bioteknologi Jurusan Biologi Fakultas Matematika dan IImu Pengetahuan Alam Universitas Bengkulu.

\section{Isolasi Bakteri yang Berasosiasi dengan Spons Aplysina sp.}

Bagian tubuh spons ditimbang dengan berat $1 \mathrm{gr}$, digerus dengan mortal dan alu untuk kemudian diencerkan dengan aquades steril sebanyak $9 \mathrm{ml}$. Selanjutnya dibuat suspensi dari pengenceran 10-1 sampai 10-3 sebanyak dua kali pengulangan. Pada setiap pengenceran dipipet $0,1 \mathrm{ml}$ secara aseptik dan kemudian disebar ke dalam cawan petri steril yang telah berisi media agar - agar Sea Water Complete (SWC), kemudian diinkubasi di inkubator pada suhu $37^{\circ} \mathrm{C}$ selama $12-24$ jam. Isolat yang tumbuh pada media dilakukan skrining berdasarkan karakter yang berbeda, kemudian dilakukan purifikasi untuk tahap selanjutnya.

\section{Uji Aktivitas Bakteri Penghasil Senyawa Bioaktif Melalui Uji Tantang, Supernatan dan Pelet}

Uji aktivitas bakteri penghasil senyawa bioaktif melalui uji tantang dilakukan menggunakan mikrob dan khamir patogen uji, yaitu S.aureus, $E$. coli, $P$. auroginosa dan $C$. albicans. Penyiapan mikrob patogenuntuk uji antagonis dilakukan dengan membuat kultur mikrob patogen pada media TSB (Tryptic Soy Broth) dan untuk khamir pathogen menggunakan media PDB (Potato Dextrose Broth) selama 24 jam. Kemudian sebanyak $1 \mathrm{ml}$ kultur mikrob patogen dimasukkan kedalam $40 \mathrm{ml}$ media agar TSA 
(Tryptic Soy Agar) yang masih cair, lalu dituang kedalam cawan petristeril. Setelah media agar TSA (Tryptic Soy Agar) yang telah padat mengandung kultur mikrob patogen, isolat bakteri laut yang akandilakukan penapisan ditotolkan kedalam media agar tersebut menggunakan ose. Kemudian dilakukan inkubasi pada inkubator dengan suhu $37^{\circ} \mathrm{C}$ selama $12-24$ jam. Pengujian dengan khamir patogen dilakukan dengan metode yang sama, hanya saja menggunakan media PDA (Potato Dextrose Agar). Hasil positif ditunjukkan oleh adanya zona bening disekitar koloni (Wahyudi et al., 2018).

Isolat yang akan digunakan untuk uji aktivitas antimikrob menggunakan supernatan dikulturkan pada media cair SWC (starter) selama 24 jam. Sebanyak 1,5 mL starter disentrifugasi pada kecepatan 10.000 rpm selama 5 menit di dalam tabung mikro, supernatan hasil dari proses sentrifugasi dipisahkan untuk kemudian digunakan pada uji antagonis terhadap mikrob uji. Uji antagonis dilakukan dengan menggunakan kertas cakram steril yang sebelumnya telah ditetesi supernatan sebanyak $20 \mu \mathrm{L}$. Kemudian kertas cakram dikeringkan selama 10-15 menit, lalu diletakkan di atas media agar yang mengandung mikrob uji. Hasil positif ditunjukkan dengan keberadaan zona bening disekitar kertas cakram. Uji aktifitas melalui pelet menggunakan metode yang sama dengan supernatan, dengan terlebih dahulu melarutkan pelet pada \pm 150 $\mu \mathrm{L}$ supernatan sehingga akan mengalami pemekatan 10 kali dari volume awal starter yang ada di dalam tabung mikro (Wahyudi et al., 2018).

\section{Identifikasi Isolat Potensial Bakteri yang Berasosiasi dengan Spons Aplysina sp.}

Karakteristik isolat yang menghasilkan senyawa bioaktif ditandai dengan terbentuknya zona bening disekitar isolat. Isolat potensial kemudian diukur berdasarkan besarnya spektrum zona bening. Kemudian, isolat terpilih tersebut diidentifikasi secara morfologi melalui pewarnaan gram, serta uji biokimia yang terdiri dari uji karbohidrat, uji sitrat, uji katalase, uji urea, dan uji motilitas.

\section{HASIL DAN PEMBAHASAN}

\section{Total Isolat Bakteri yang Berasosiasi dengan Spons Aplysina sp}

Isolasi bakteri yang berasosiasi dengan spons Aplysina sp.Diambildari Pulau Enggano yaitu di pulau Dua $\left(5^{\circ} 44^{\prime}-5^{\circ} 45^{\prime}\right.$ LS dan $102^{\circ} 39-102^{\circ} 40^{\prime}$ BT) pada kedalaman sekitar 1-2 meter dengan suhu air laut $25-27{ }^{\circ} \mathrm{C}$. Hasil isolasi yang dilakukan dari spons Aplysina sp. menghasilkan 16 isolat bakteri berdasarkan penapisan menggunakan karakter morfologi koloni. Pengamatan jumlah total koloni bakteri yang diperoleh ditampilkan pada (Tabel 1). 
Tabel 1. Jumlah bakteri yang diisolasi dari sampel spons Aplysina sp.

\begin{tabular}{lccc}
\hline Kode & \multicolumn{3}{c}{ Pengenceran } \\
\cline { 2 - 4 } sampel & $10^{-1}$ & $10^{-2}$ & $10^{-3}$ \\
\cline { 2 - 4 } ENG 1 & 28 & 8 & 3 \\
ENG 2 & 25 & 34 & 35 \\
ENG 3 & 102 & 16 & 12 \\
\cline { 2 - 4 } & 155 & 58 & 50
\end{tabular}

Total isolat $=263$

Keterangan : ENG 1=Aplysina sp. Pulau Enggano bagian Terminal, ENG2 =Aplysina sp. Pulau Enggano bagian Subterminal, ENG 3 Aplysina sp. Pulau Enggano bagian Central

Hasil isolasi bakteri pada media agar-agar SWC (Sea Water Complete) di Pulau Enggano hasil pengenceran $10^{-1}$ diperoleh sebanyak 155 koloni. Pada pengenceran $10^{-2}$ diperoleh sebanyak 58 dan $10^{-3}$ diperoleh sebanyak 50. Semakin tinggi tingkat pengenceran maka tingkat kerapatan sel bakteri juga akan berkurang sehingga akan didapatkan bakteri dengan kuantitas yang dapat dihitung.
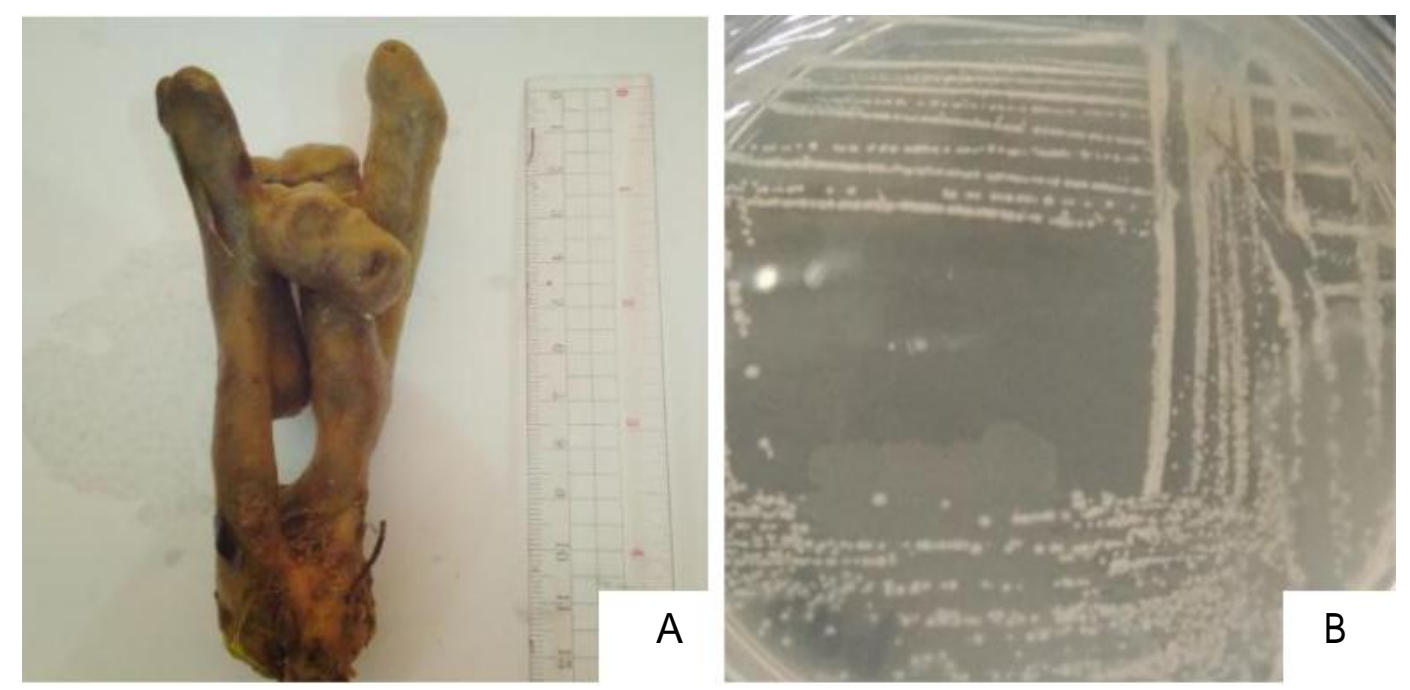

Gambar 1. Spons Aplysina sp. dari Pulau Dua, Enggano (A); Karakteristik morfologi isolat ENG-04 dari bakteri yang berasosiasi dengan spons Aplysina sp. pada media agar SWC (Sea Water Complete) (B)

\section{Uji Aktivitas Bakteri Laut yang Barasosiasi dengan Spons Aplysina sp. dengan Menggunakan Uji Tantang, Supernatan, dan Pelet}

Uji aktivitas bakteri laut yang berasosiasi dengan spons Aplysina sp. dilakukan terhadap 16 isolat murni hasil isolasi melalui dua perlakuan, 
yaitu dengan cara menotolkan langsung isolat ke atas media TSA (TrypticSoy Agar) serta dengan menggunakan kertas cakram. Hasil ujiditunjukkan pada Gambar 2.

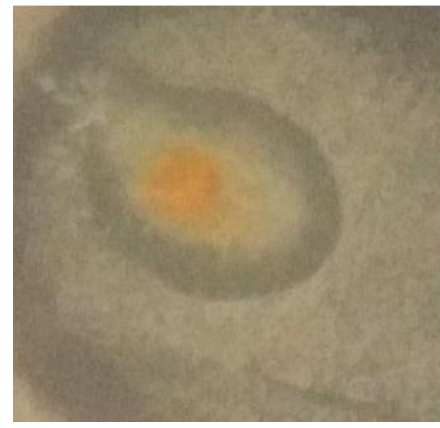

$1 \mathrm{~A}$

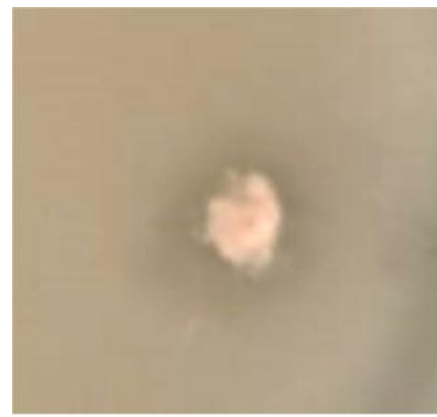

$2 A$

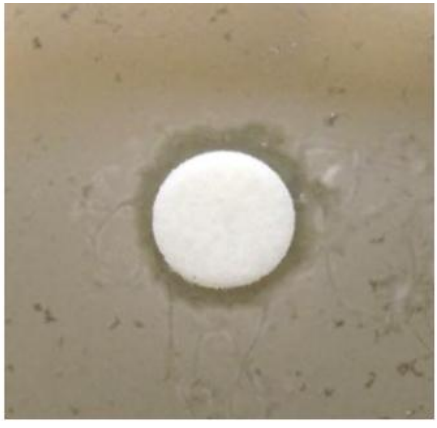

1B

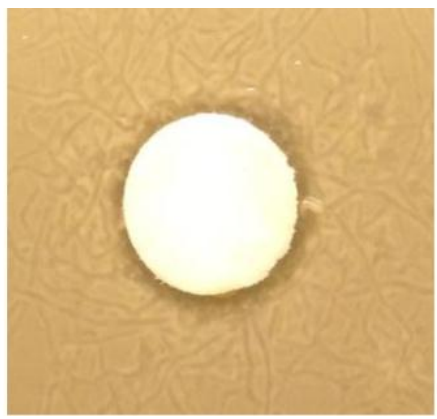

2B

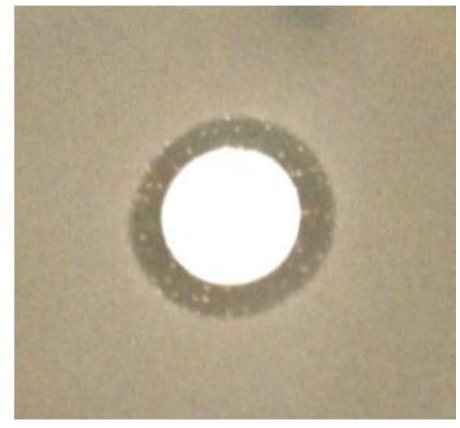

1C

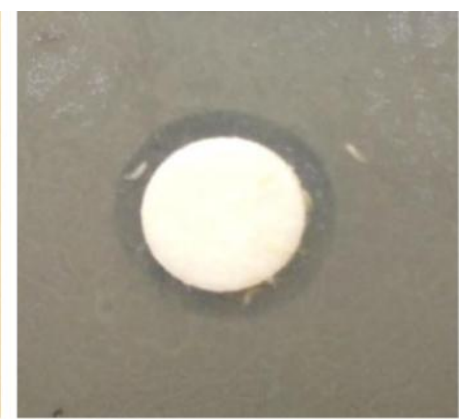

2C

Gambar 2. Zona hambat yang dihasilkan dari isolat ENG-4 terhadap pertumbuhan mikrob patogen E. coli (1), S. aureus (2) dan Uji antagonis menggunakan kultur sel bakteri (A), Supernatan (B), dan Pelet (C)

Tabel 2. Aktivitas antimikrob dari isolat ENG-4 bakteri yang berasosiasi dengan spons Aplysina sp. dengan menggunakan uji tantang

\begin{tabular}{|c|c|c|c|c|c|}
\hline No & $\begin{array}{c}\text { Tahap } \\
\text { Uji }\end{array}$ & E. colli & S. aureus & $P$. aeruginosa & C. albicans \\
\hline 1 & Biakan & $0.5(+)$ & $0.2(+)$ & $0(-)$ & $0(-)$ \\
\hline 2 & $\begin{array}{l}\text { Super- } \\
\text { natan }\end{array}$ & $3.1(+)$ & $2.5(+)$ & $0(-)$ & $0(-)$ \\
\hline 3 & Pelet & $5,3(++)$ & + & $0(-)$ & $0(-)$ \\
\hline
\end{tabular}

Keterangan: $(+)$ : luas zona hambat $1-5 \mathrm{~mm},(++)$ : luas zona hambat $5-$ $10 \mathrm{~mm}$.

Hasil pengujian isolat ENG-4 terhadap aktivitas antimikrob dengan menggunakan biakan menunjukan luas zona hambat yang berbeda beda. Pengujian terhadap bakteri $E$. colli menghasilkan aktivitas zona hambat sebesar $0,5 \mathrm{~mm}$, terhadap bakteri $S$. aureus menghasilkan 
aktivitas zona hambat sebesar $0,3 \mathrm{~mm}$, sedangkan pada bakteri $P$.aeruginosa dan jamur $C$. albicans tidak menunjukan zona hambat.

Pengujian isolat ENG-4 menggunakan supernatan menunjukan luas zona hambat yang berbeda - beda. Pengujian terhadap bakteri $E$. colli menghasilkan aktivitas zona hambat sebesar $3,1 \mathrm{~mm}$, terhadap bakteri S.aureus menghasilkan aktivitas zona hambat sebesar $2,5 \mathrm{~mm}$, sedangkanpada bakteri $P$. aeruginosa dan khamir $C$. albicans tidak menunjukan zona hambat. Pengujian isolat ENG-4 menggunakan pellet menunjukan luas zona hambat yang berbeda - beda. Pengujian terhadap bakteri $E$. colli menghasilkan aktivitas zona hambat sebesar $5,3 \mathrm{~mm}$, terhadap bakteri S.aureus menghasilkan aktivitas zona hambat sebesar $2,5 \mathrm{~mm}$, sedangkanpada bakteri $P$. aeruginosa dan khamir $C$. albicans tidak menunjukan zona hambat. Senyawa bioaktif yang dimiliki oleh suatu bakteri memiliki banyak fungsi yang berkaitan dengan kelangsungan hidupnya. Diantaranya adalah berperan sebagai faktor virulensi antara mikrob dengan tanaman, pencegahan fagositosis oleh amuba predator, serta sebagai suatu bentuk interaksi simbiotik antara mikrob dengan organisme inang (Schmid et al., 2001).

Menurut Davis \& Stout (1971) klasifikasi kekuatan daya hambat dapat dikelompokan menjadi beberapa kategori yaitu kategori sangat kuat diameter hambat $\geq 20 \mathrm{~mm}$, kuat $10-20 \mathrm{~mm}$, sedang $5-10 \mathrm{~mm}$, dan lemah $\leq$ $5 \mathrm{~mm}$. Hasil uji aktivitas bakteri laut yang berasosiasi dengan spons Aplysina sp. menggunakan uji tantang aktivitas zona hambat yangberbeda - beda. Perbedaan luas zona hambat isolat ENG-4 terhadap masing masing mikrob patogen tersebut diduga karena keragaman senyawa bioaktif yang dimiliki oleh isolat tersebut serta kemampuan resistensi dari setiap jenis mikrob patogen (Davis dan Stout, 1971). Selain itu menurut Nofiani et al.,(2009), roduksi senyawa bioaktif dari bakteri juga berkaitan dengan fase pertumbuhan bakteri. Ketika bakteri memasuki fase logaritmik, maka pada fase ini bakteri akan melakukan pembelahan sel dan membutuhkan banyak nutrisi yang tersedia pada media. Ketika nutrisi pada media berkurang, pada fase ini bakteri akan memasuki fase stationer dan diduga akan terjadi produksi senyawa bioaktif salah satunya adalah senyawa antimikrob.

\section{Identifikasi Isolat Bakteri ENG-4 yang Berasosiasi dengan Spons Aplysina sp.}

Identifikasi bakteri dilakukan untuk mengetahui karakter bakteri melalui pengamatan secara morfologi dan biokimia (Tabel 3). Identifikasi secara morfologi dilakukan dengan dua pengamatan, yaitu secara makroskopis dan mikroskopis. Pengamatan makroskopis dilakukan dengan melihat karakter morfologi koloni isolat potensial yang berasosiasi dengan spons Aplysina sp. Pengamatan secara mikroskopis dilakukan dengan pewarnaan Gram. Pewarnaan Gram dilakukan untuk membedakan dua kelompok bakteri, yaitu bakteri Gram positif dan bakteri Gram negatif. 
Tabel 3. Pengamatan morfologi dan uji biokimia isolat bakteri yang berasosiasi dengan spons Aplysina sp. yang berasal dari Pulau Enggano

\begin{tabular}{|c|c|c|c|c|c|c|c|c|}
\hline \multirow[b]{2}{*}{ KodeSampel } & \multicolumn{7}{|c|}{ PengamatanMorfologi } & \multirow[b]{2}{*}{ warna } \\
\hline & \multicolumn{4}{|c|}{ Tepi } & $\begin{array}{c}\text { Permu- } \\
\text { kaan }\end{array}$ & $\begin{array}{c}\text { Penam- } \\
\text { pakan }\end{array}$ & Elevasi & \\
\hline \multirow[t]{5}{*}{ ENGG-4 } & & & tire & & Smooth & Circular & Convex & Kuning \\
\hline & \multicolumn{8}{|c|}{ UjiBiokimia } \\
\hline & \multirow[t]{2}{*}{$\mathrm{K}$} & Si & Mo & $U$ & \multicolumn{3}{|c|}{ UjiGulagula } & \\
\hline & & & & & G & $\mathrm{M}$ & L & S \\
\hline & + & + & + & - & + & + & - & + \\
\hline
\end{tabular}

Keterangan: $\mathrm{K}=$ Katalase; $\mathrm{Si}=$ Sitrat; $\mathrm{Mo}=$ Motilitas; $\mathrm{U}=$ Urea; $\mathrm{G}$ =Glukosa, $\mathrm{M}=$ Maltosa, $\mathrm{L}=$ Laktosa, $\mathrm{S}=$ Sukrosa

Berdasarkan hasil pewarnaan Gram, dan uji biokimia, isolat ENG-4 diduga kedekatan genusnya dengan bakteri genus Bacillus dengan ciri ciri koloni berwarna kuning, bersifat Gram positif, motil, katalase positif. Isolat ENG-4 memiliki bentuk batang dengan penataan diplobasil, mampu memfermentasikan glukosa, sukrosa, dan maltose tetapi tidak mampu memfermentasi laktosa, mampu menghidrolisis sitrat serta tidak mampu menghidrolisis urea. Hasil pewarnaan Gram isolat ENG-4 dapat dilihat pada Gambar 3.

Klasifikasi isolat ENG-4

(Vos et al., 2009):

Kingdom : Bacteria

Filum : Firmicutes

Kelas : Bacilli

Ordo : Bacillales

Famili : Bacilliaceae

Genus : Bacillus

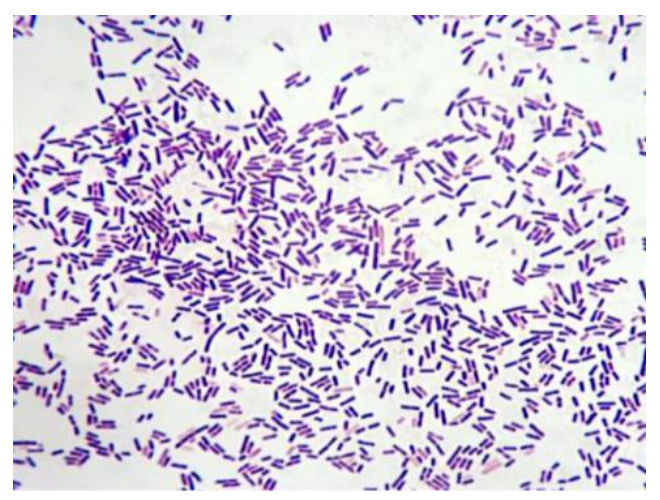

Gambar 3. Pewarnaan Gram isolat ENG-4 menggunakan Mikroskop Binokuler dengan perbesaran $1000 \mathrm{x}$

Vos et al., (2009) menyatakan bahwa genus Bacillus merupakan bakteri berbentuk batang, penataan secara tunggal atau berpasangan dalam rantai pendek, bersifat Gram positif, terbentuk spora, bentuk koloni bulat, cembung, dengan permukaan yang halus, katalase positif, oksidase positif atau negatif, serta tidak dapat menghidrolisis urea. Vos et al., (2009) enyatakan bahwa genus Bacillus merupakan bakteri berbentuk batang, penataan secara tunggal atau berpasangan dalam rantai pendek, bersifat Gram positif, terbentuk spora, bentuk koloni bulat, cembung, 
dengan permukaan yang halus, katalase positif, oksidase positif atau negatif, serta tidak dapat menghidrolisis urea.

\section{KESIMPULAN}

Sebanyak 263 isolat bakteri berhasil diisolasi dari spons Aplysina $\mathrm{sp}$ asal Pulau Enggano. 16 isolat dipilih berdasarkan perbedaan karakter morfologi koloni. Isolat ENG-4 memiliki aktivitas menghambat pertumbuhan dua mikrob patogen yaitu E. coli sebesar dan $S$. Aureus yang diuji menggunakan pellet dan supernatant. Isolat ENG-4 memiliki kedekatan dengan genus Bacillus.

\section{UCAPAN TERIMA KASIH}

Penulis mengucapkan terima kasih kepada Lembaga Penelitian dan Pengabdian Masyarakat (LPPM) Universitas Bengkulu melalui Hibah Penelitian Pembinaan Tahun 2019 nomor: 2152/UN30.15/LT/2019 tanggal 10 juli 2019 kepada Risky Hadi Wibowo. Penulis juga mengucapkan terima kasih kepada masyarakat di Pulau Enggano, Provinsi Bengkulu serta kepada seluruh pihak yang telah membantu penyelesaian penelitian ini.

\section{DAFTAR PUSTAKA}

Davis, W. W., Stout, T. R. 1971. Disc Plate Method of Microbiological Antibiotic Assay. Applied Microbiology, 22(4), 659-665.

Hentschel, Ute., Michael., Schmid, Michael, Wagner., Lars, Fieseler., Christine., Gernert, Jorg., Hacker. 2001. Isolation and phylogenetic analysis of bacteria with antimicrobial activities from the Mediterranean sponges Aplysina aerophoba and Aplysina cavernicola. FEMS Microbiology Ecology, 35: 305- 312.

Nofiani, R., Nurbetty, S., \& Sapar, A. 2009. Aktivitas Antioksidan dan Komponen Bioaktif Kerang Pisau (Solen spp.). IImu Kelautan, 16, 119-124.

Ratnakomala, S., Apriliana, P., Fahrurrozi, Lisdiyanti, P., Kusharyoto, W. 2016. Aktivitas Antibakteri Aktinomisetes Laut Dari Pulau Enggano. Jurnal IImu - IImu Hayati, 15(3), 207-319.

Schmid, M., Wagner, M., Fieseler, L., \& Gernert, C. 2001. Isolation and phylogenetic analysis of bacteria with antimicrobial activities from the Mediterranean sponges Allysine aerophoba and Aplysinacavernicola. FEMS Microbioly Ecology, 35, 305-312. 
Senoaji,G., Kehutanan, J., Pertanian, F., Bengkulu, U., Daya, B., Sumatera, P. 2007. Daya dukung lingkungan dan kesesuaian lahan dalam pengembangan pulau Enggano bengkulu. JurnalBumi Lestari, 9(2), 159-166.

Taylor, M. W., Radax, R., Steger, D., Taylor, M. W., Radax, R., Steger, D., \& Wagner, M. 2007. Sponge-Associated Microorganisms: Evolution, Ecology, and Biotechnological Potential Sponge-Associated Microorganisms: Evolution, Ecology, and Biotechnological Potential. Microbiology and Molecular Biology Reviews, 71(2), 295.

Vos, P. De, George M. Garrity, Jones, D., Krieg, N. R., Ludwig, W., Rainey, F. A., Whitman, W. B. 2009. Bergey's Manual Of Systematic Bacteriology Second Edition The Firmicutes (Second Edition). New York (US): Springer.

Wahyudi, A.T., Priyanto, J.A., Maharsiwi, W., Astuti, R.I. 2018. Screening and Characterization of Sponge-Associated Bacteria Producing Bioactive Compounds Anti- Vibrio sp. American Journal of Biochemistry and Biotechnology, 3, 221-229.

Webster, N. S., \& Hill, R. T. 2001. The Culturable Microbial Community Of the Great Barrier Reef Sponge Rhopaloeides Odorabile is Dominated By An A -Proteobacterium. Marine Biology, 138, 843851. 